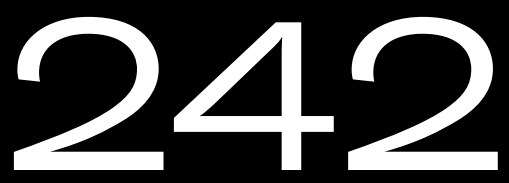

\title{
Em movimento: Carpeaux e a última ditadura militar brasileira
}

\section{Eduardo Gomes Silva}

Após o golpe civil-militar de 1964, Carpeaux transformou sua coluna de política internacional do Correio da Manhã em uma trincheira de oposição à ditadura. Quando o espaço deixou de existir, Carpeaux partiu para outras frentes de batalha, que incluem cerimônias de formatura, imprensa alternativa e uma película de $16 \mathrm{~mm}$.

After the civil-military coup of 1964, Carpeaux turned his international politics column at Correio da Manhã into an adversary trench against the dictatorship.

When that space ceased to exist, Carpeaux proceeded to other battlefronts, which include graduation ceremonies, alternative press and a $16 \mathrm{~mm}$ film. DOI 10.11606/issn.2447-8997.teresa.2020.152803 

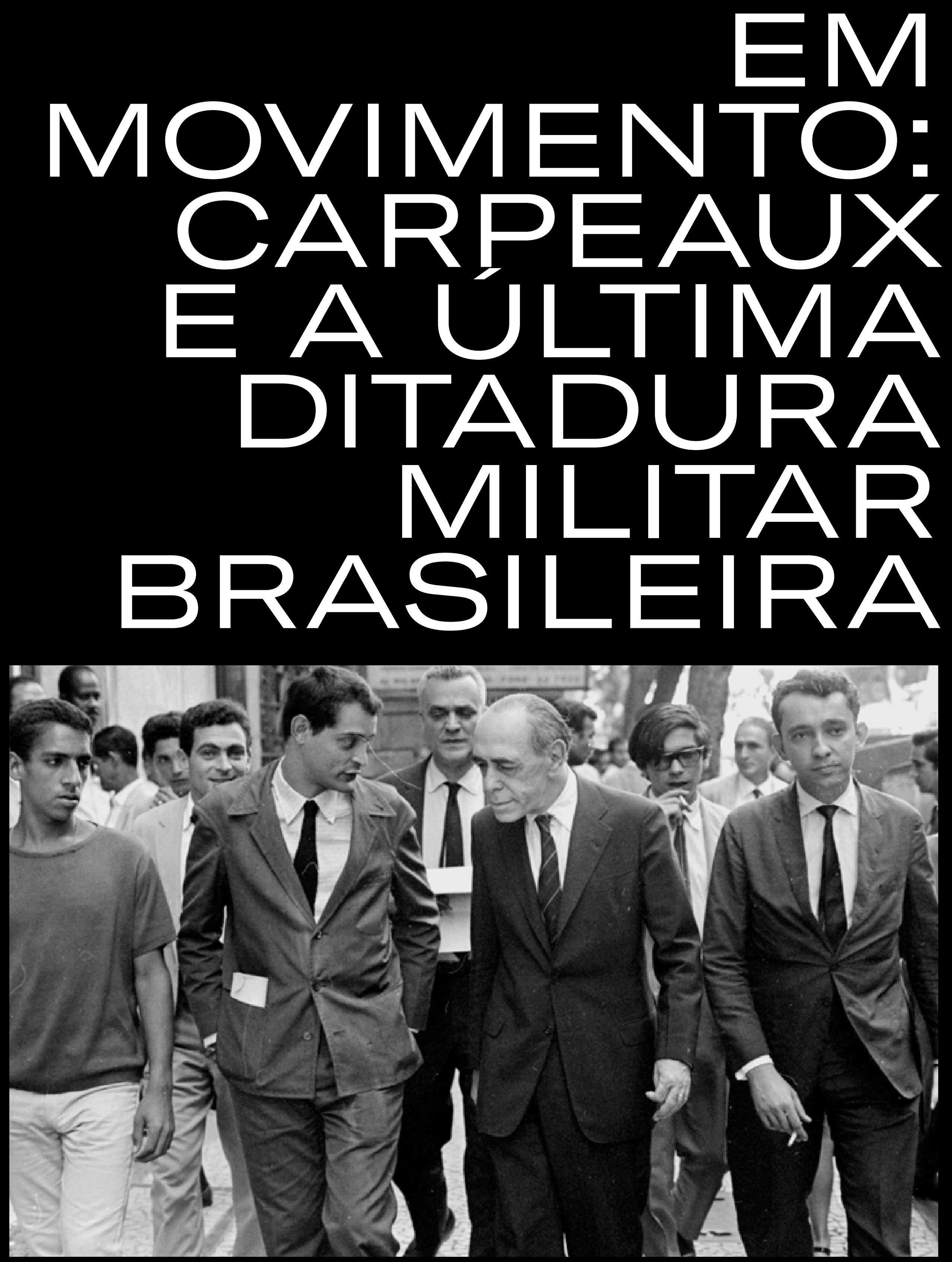

Eduardo Gomes Silva 
"Vladimir Palmeira não se esquece do trabalho que deu aquele companheiro de 68 anos, insistindo em passar com o enterro pelo

Palácio da Guanabara. 'Ele queria exibir o corpo [do estudante assassinado Edson Luís] para o governador. Imagina a situação' relembra Vladimir - 'eu, o radical, tendo que dizer para o velho: não dá pé, Carpeaux, é provocação'. Para convencer o renitente militante, o presidente da UME teve que usar um argumento técnico: 'o problema, Carpeaux, é que a gente já marcou com os sindicatos, os estudantes. Não dá para mudar sem consultá-los'".

Vladimir Palmeira, em depoimento a Zuenir Ventura, 1968: o ano que não terminou

"Mais liberdade!". Possivelmente foram essas as últimas palavras de Otto Maria Carpeaux, acompanhadas de um gesto brusco que o separou do emaranhado de tubos e sondas que ainda o mantinha vivo. ${ }^{1}$ No quarto, presenciando a voluntariosa cena, somente Helena, a companheira de uma vida inteira e para quem Carpeaux, ao final da sua, pedia que o ajudasse a morrer.

Certa vez, perguntado como gostaria que fosse a sua morte, Carpeaux respondera: "sem aviso prévio" - possivelmente inspirado no exemplo do pai, que chegou em casa após mais um dia de trabalho, jantou, dedilhou algumas notas ao piano e, instantes depois, sofreu um ataque cardíaco fulminante. Carpeaux não teve o seu desejo realizado. Sempre arredio a médicos, certa tarde de janeiro de 1978, surpreendeu Helena ao dizer que talvez precisasse de um. Tinha ido almoçar com amigos no centro da cidade e só com muito esforço conseguira retornar à rua República do Peru, em Copacabana, residência do casal. Estava sofrendo um enfarte. Foi levado ao hospital Pró-Cardíaco naquela mesma noite. Já internado, dois dias depois sofreria outro enfarte, desta vez mais violento.

"Que posso esperar agora da vida? Tive dois enfartes, estou com enfisema e não consigo parar de fumar”, dissera. Conservar-se lúcido até o derradeiro momento parecia ser sua resposta para a própria indagação retórica. Durante os quinze dias em que estivera internado, Carpeaux,

1 As informações foram colhidas nos seguintes necrológios: "Otto Maria Carpeaux (1900-1978)". Veja, 8 fev. 1978; "Internado Oto Maria Carpeaux" [sic]. Folha de S.Paulo, 25 jan. 1978; "Otto Maria Carpeaux morre no Rio aos 77 anos”. Folha de S.Paulo, 4 fev. 1978; “Carpeaux é sepultado como pediu: com amigos, sem padres e sem flores". Jornal do Brasil, 5 fev. 1978. 
famoso pela sua capacidade mnemônica, passava o tempo revisando títulos de livros, nomes de autores e trechos de música. Um dia antes de morrer e já num estado de saúde crítico - concorria para este quadro complicações renais e uma pneumonia dupla - teria socorrido Helena com o nome de um autor de que ela mesma não se lembrava.

“Tudo para acabar assim", lamentou certa vez a um dos amigos que o visitara no Pró-Cardíaco - lamento acompanhado de uma lágrima no canto do olho. No dia 3 de fevereiro de 1978, a queixa cedeu à ação: Carpeaux desvencilhou-se da parafernália médica em busca de liberdade e, aproximadamente às duas da tarde, partiu - "ao chamado da noite". ${ }^{2}$

Os amigos foram chegando aos poucos e o velório deu-se na capela sete do cemitério São João Batista - a poucos metros do hospital em que estivera internado. Ao enterro, marcado para as onze da manhã do dia 4 de fevereiro, um sábado de Carnaval, compareceram pouco mais de cinquenta pessoas. Elas acompanharam uma cerimônia simples, de apenas quinze minutos - tempo do trajeto fúnebre entre a capela mortuária e a sepultura 20.592 do São José Batista. Respeitouse o desejo manifesto por Carpeaux para que seu corpo não fosse encomendado, tampouco que houvesse discursos. Não havia flores ou mesmo qualquer insígnia religiosa em sua urna funerária, também desejo de Carpeaux - judeu de nascimento, católico convertido em idade adulta - em sugerir ou demonstrar a defecção religiosa do final da vida.

Se sua vida, segundo ele próprio, havia sido rasa de grandes acontecimentos e há muito já estava enquadrada numa estrutura, espécie de "plot bem inventado", ${ }^{3}$ após aquela manhã de fevereiro o austríaco que vivera metade da vida na Europa e a outra no Brasil não seria mais responsável ou não poderia mais acompanhar ou intervir na história de sua própria vida, ele que poucos meses antes havia expressado que não queria que lhe fizessem a biografia. O nome que adotara quando de sua vinda ao Brasil e pelo qual ficara conhecido entre nós já não poderia assinar qualquer artigo, livro, manifesto.

A metáfora cinematográfica do plot como roteiro de uma vida, aparentemente deslocada por se tratar de um crítico literário, foi sugerida

\footnotetext{
2 "Como Petrarca, pace non trovo, a não ser que a encontrarei no último momento, quando a noite chamará para partir e quando, tendo visto tudo pela última vez, me lembrarei do meu Dante, com versos dele. $M a$ la notte rissurge e oramai / è da partir, ché tutto avem veduto". Cf. CARPEAUX, Otto Maria. "Meu Dante". In: Instituto cultural ítalo-brasileiro, São Paulo, n. 5, 1965, p. 28.

3 PEREz, Renard. “Otto Maria Carpeaux”. In: PEREz, Renard (org.). Escritores brasileiros contemporâneos. $2^{\text {a }}$ série. Rio de Janeiro: Editora Civilização Brasileira, 1964, p. 282.
} 
pelo próprio Carpeaux em resposta a uma das inúmeras tentativas de lhe construírem uma trajetória: "Com exceção de minha aventurosa fuga em 1938 e de certas experiências no Brasil, minha vida não teve nada de anedótico. [...] Se me afigura hoje como se fosse enredo de um romance, de um plot bem inventado". ${ }^{4}$ Embora publicada em 1964, na segunda série do compêndio Escritores brasileiros contemporâneos, o perfil dedicado a Carpeaux data de um ano antes, como assegura o seu autor, Renard Perez. Colega de redação do crítico no Correio da Manhã, Renard Perez atualizaria o perfil em 1968, a fim de inserir um plot point sofrido por Carpeaux, pelo matutino carioca e pelo país em 1964: a tomada do poder pelos militares e civis dos mais diversos setores da sociedade brasileira.

Se pudéssemos resumir em poucas linhas como o golpe de 1964 e a ditadura militar impactaram a vida de Carpeaux, articularíamos palavras como censura, cerceamento, perseguição, tentativas de silenciamento. Significantes que, embora verdadeiros, podem produzir uma falsa ideia de rompimento da atuação intelectual e política de Carpeaux pós1964. É o que encontramos, por exemplo, no verbete sobre Carpeaux do Dicionário histórico-biográfico brasileiro: "Findo o período áureo do Correio da Manhã , Carpeaux afastou-se do jornalismo diário, passando a dedicar-se, junto com Antônio Houaiss, à confecção das enciclopédias Delta Larousse e Mirador".

Houve tudo isso, assim como também houve um deliberado abandono por parte de Carpeaux daquilo que denominou de "círculo de amigos da literatura" e de seu próprio ciclo como crítico literário: "Minha cabeça e meu coração estão em outra parte. O que me resta, de capacidade de trabalho, pertence ao Brasil e à luta pela libertação do povo brasileiro", ${ }^{5}$ escreveu em 1968. Morto dez anos depois, Carpeaux não pôde presenciar a redemocratização do país. Talvez isto ajude a explicar o amargor dos seus últimos dias - "Tudo para acabar assim”...

Em um estudo de maior fôlego, ${ }^{6}$ um dos nossos intuitos foi ir além daquelas derradeiras palavras de Carpeaux. Ou melhor, nosso esforço foi

\footnotetext{
4 Ibidem.

5 "Nota Prévia: um amigo meu calculou que eu tinha publicado na imprensa brasileira, entre 1941 e 1966, mais ou menos 1.500 artigos sobre assuntos literários. [...] Fiz uma seleção rigorosa: só escolhi trabalhos que, por este ou aquele motivo, ainda hoje possam inspirar interesses ao círculo de amigos da literatura. Mas já não me incluo nesse círculo. Considero encerrado o ciclo. Minha cabeça e meu coração estão em outra parte. O que me resta, de capacidade de trabalho, pertence ao Brasil e à luta pela libertação do povo brasileiro". CARPEAUX, Otto Maria. Vinte e cinco anos de literatura. Rio de Janeiro: Editora Civilização Brasileira, 1968, p. XIV.

6 Imagens de Otto Maria Carpeaux: esboço de biografia. Tese (Doutorado em História Cultural) - Florianópolis: Centro de Filosofia e Ciências Humanas, Universidade Federal de Santa Catarina, 2015.
} 
o de dotar de significantes o "tudo" que a frase privilegia. Houve produção intelectual, houve atividade política, houve resistência por parte de Carpeaux entre 1964 e 1978. Foi dessas experiências, e não somente da censura, da captura e das tentativas de silenciamento que quisemos dar testemunho.

Desde então, apostamos na forma fragmentária para tentar acompanhar Carpeaux nos muitos círculos e frentes em que passou a atuar após o golpe de 1964. A natureza díspar de suas atividades daquele período e, consequentemente, a ausência de seus registros em arquivos tradicionais, impuseram-nos a tarefa de construir o que denominamos "imagens críticas de Otto Maria Carpeaux" - fragmentos de suas ações e movimentos, "montados" a partir de uma dada cesura: a do nosso presente. ${ }^{7}$

À nossa inspiração e dívida para com o conceito de história benjaminiano, patente naquele estudo, soma-se um compromisso de resistir à monumentalização do passado, tal qual a caracterizou Nietzsche: uma escrita da história sistemática, estanque e morta. ${ }^{8}$ Ademais, no exercício de acompanhar e dar forma às experiências fragmentárias de Carpeaux, deparamo-nos com uma distinção pertinente entre os tipos de experiências e formas possíveis de sua escrita pela história: “A revolução e o povo produziam cartões-postais e todo tipo de souvenir, enquanto a guerrilha e o grupo espontâneo em luta clandestina [...] geravam afetos, sensações comuns que não exigiam uma moldura na parede". ${ }^{9}$

Frutos das experiências de Carpeaux num contexto em que as perspectivas progressistas foram substituídas pela aspereza de um projeto autoritário e excludente, as "imagens críticas" que se seguem não buscam enquadrá-lo, mas tornar presentes os seus anseios, fazer justiça aos seus esforços de "libertação do povo brasileiro". Buscam, enfim, intervir num contexto atual de relativização dos danos causados por aquele projeto. São breves, são fragmentárias essas imagens. Esperamos, todavia, que sejam potentes.

\section{ENQUANTO POSSÍVEL, A LINGUAGEM ESÓPICA}

Mesmo tendo conhecimento da intricada rede responsável pela escrita, negociação e publicação de um editorial, sobretudo em tempos de crise

7 Benjamin, Walter. Passagens. Organização de Willi Bolle. Tradução de Irene Aron et alii. Belo Horizonte; São Paulo: Editora UFMG; Imprensa Oficial do Estado de São Paulo, 2006, p. 505.

8 NIETZSChe, Friedrich W. Segunda consideração intempestiva. Rio de Janeiro: Relume-Dumará, 2003.

9 vila-matas, Enrique. Não há lugar para a lógica em Kassel. Tradução de Antônio Xerxenesky. São Paulo: Cosac Naify, 2015, p. 143. Por sua vez, Vila-Matas atribui o aforisma ao escritor, poeta e ensaísta basco

Sebastià Jovani. 
política, podemos constatar a presença de Carpeaux nos dois publicados pelo Correio da Manhã em 1964, o "Basta!"10 e o "Fora!"." Como redator editorialista e responsável pela pauta internacional, cabia a Carpeaux o reboque dos editoriais do Correio. Segundo Carlos Heitor Cony, naqueles que viriam a ser os derradeiros dias do Governo Goulart, era desejo de Carpeaux "pisar forte, com um editorial virulento contra Jango". ${ }^{2}$ Mas, se no editorial de 31 de março havia a admissão de que Goulart cumprisse integralmente o seu mandato "de acordo com a Constituição", desde que desistisse de sua "política atual" por estar "perturbando uma nação em desenvolvimento, e ameaçando de levá-la à guerra civil”, no de $1^{\circ} \mathrm{de}$ abril essa possibilidade já não mais figurava no horizonte do Correio da Manhã. Pela "omissão dos dois primeiros anos" e pela "conspiração" contra a República, "verificáveis" pelos últimos "pronunciamentos e atos", sob o ponto de vista daquele jornal só havia uma atitude digna a ser tomada por João Goulart: devolver ao "Congresso [...], ao povo o mandato que ele não soube honrar".

Visto com os olhos da história, esses editoriais separam cronologicamente dois momentos distintos do país. Separam democracia e ditadura. À prova de truísmos, tal mudança foi sentida pelo próprio Correio passados apenas três dias da publicação de “Basta!”, quando o velho matutino de estirpe liberal e seus jornalistas perceberam a natureza do "novo regime" e redarguiram às ações terroristas, à vocação ditatorial e às ameaças de setores do consórcio golpista. ${ }^{13}$

Com sete dias do novo regime, uma nota de destaque na primeira página do Correio denunciava a pilhagem e a queima de milhares de exemplares daquele matutino nas calçadas do Rio de Janeiro, "perante grupos de populares". ${ }^{14}$ Nesta nota podemos encontrar aspectos que perpassaram uma das linhas de combate do jornal à ditadura militar, associando-a à experiência nazifascista europeia. Intuímos nesta linha traços da argumentação de Carpeaux, ele mesmo um fugitivo do Terceiro Reich, desenvolvida obliquamente nos reboques dos editoriais e em sua coluna de política internacional no Correio. Antevemos, por fim, no ato

\footnotetext{
10 Correio da Manhã, Rio de Janeiro, 31 mar. 1964, p. 1.

11 Correio da Manhã, Rio de Janeiro, $1^{\circ}$. abr. 1964, p. 1.

12 cony, Carlos Heitor. "Um basta no basta”. Folha de S.Paulo, São Paulo, 30 nov. 2002, p. 2.

13 “Terrorismo, não!”. Correio da Manhã, Rio de Janeiro, 3 abr. 1964, p. 1; “Duas ameaças graves”. Correio da Manhã, Rio de Janeiro, 4 abr. 1964, p. 1.

14 “Pilhagem”. Correio da Manhã, Rio de Janeiro, 7 abr. 1964, p. 1.
} 
de "intolerância e barbárie" denunciada pelo jornal, seu próprio destino: deliberadamente sufocado pela retirada de anúncios, vendido como massa falida para outras empresas de comunicação e, finalmente, fechado. ${ }^{15}$

Na página quatro do jornal, a coluna de política internacional assinada por Carpeaux aproximava, quase diariamente, dois processos históricos distintos, vivenciados e percebidos como similares pelo austríaco-brasileiro. Um deles responsável pela perseguição e por sua "impiedosa fuga no inverno", pelo "sabor amargo" do exílio, e pela "dura vergonha de bater em vão a portas fechadas e descer as escadas subidas com o último resto de esperança". ${ }^{16} \mathrm{O}$ outro, work in progress, seria o responsável pela sua saída do jornal que havia sido a sua "Verona" desde o início dos anos 1940, por um inquérito policial militar criado, acatado e transformado em ação penal, e, não menos significativo, responsável pelo seu desejo de aprofundar a luta contra a ditadura militar, mesmo que para tanto tivesse que abandonar seu ofício como ensaísta e crítico literário.

À gradual e violenta tomada de poder pelos militares e toda a sorte de perseguições postas em prática nos primeiros dias de abril de 1964 sintomaticamente denominada pelos vencedores de Operação Limpeza ${ }^{17}$ -, Carpeaux respondia, com detalhes, ao processo igualmente gradual e não menos violento da concentração de poder pelo Partido Nazista. Nos estudantes, perseguidos e resistentes de primeira hora, Carpeaux concentrava especial atenção e tecia os seus oblíquos exemplos. Foram justamente os estudantes, escrevera Carpeaux num desses artigos, "que deram na Alemanha o primeiro sinal de resistência contra Hitler". ${ }^{18}$

Ao longo deste artigo, intitulado "Os estudantes e a coincidência", Carpeaux demonstra a potência que aquele tipo de aproximação histórica, por meio do que denominou de "linguagem esópica", poderia

\footnotetext{
15 Segundo Pery Cotta, antes mesmo do AI-5, o Correio da Manhã foi sendo "esquartejado" devido à oposição ao regime militar. Primeiro, com o corte da publicidade das grandes empresas estatais. "Saía anúncio delas em qualquer jornaleco, menos no Correio". Depois, com o "corte fundo dos grandes anunciantes privados, que receberam ordens, insinuações e sugestões no sentido de não anunciar no Correio, chamado até de jornal comunista". CotTA, Pery. Calandra: o sufoco da imprensa nos anos de chumbo. Rio de Janeiro: Bertrand Brasil, 1997, p. 49.

16 Carpeaux, Otto Maria. “Meu Dante”. Op. cit., p. 27.

17 O incêndio criminoso da sede nacional da UNE, no então estado da Guanabara, é um dos exemplos das arbitrariedades postas em prática pela polícia do Exército, polícias estaduais e por agrupamentos paramilitares que antecederam ao AI-1. Uma vez promulgado - sem a dotação numérica que caracterizariam os AIs subsequentes -, criou-se a base legal para prisões, exonerações, cassações de mandatos e de direitos políticos parlamentares, intelectuais, militares, estudantes e toda a sorte de sindicatos e associações, ligados ou não ao governo Goulart. 18 CARPEUAX, Otto Maria. "Os estudantes e a coincidência”. In: O Brasil no espelho do mundo: crônicas de política internacional e nacional. Rio de Janeiro: Editora Civilização Brasileira, 1965, p. 133. Publicado originalmente no Correio da Manhã, 18 set. 1964.
} 
alcançar. "Certo que Hitler desconfiava dos estudantes. E que tomou suas medidas", ${ }^{19}$ escreveria mais adiante, arrolando medidas administrativas e legais para prejudicar estudantes ligados a certas associações alemãs. Ainda segundo Carpeaux, aqueles que tinham se "pronunciado contra a brutalidade de botas ou contra a estupidez dos que engraxavam as botas" tiveram pior destino: foram expulsos de suas respectivas universidades e proibidos de se matricular em qualquer outra. "Uma vida arruinada. E foram muitos os punidos." 20

Nos dois últimos parágrafos, a perseguição aos estudantes e o fim da liberdade das universidades, os prejuízos de tais atos para cultura da nação e a injustiça que esses tipos de ações representam para os estudantes e para "todos os intelectuais, toda a inteligência do país" são deliberadamente embaralhados por Carpeaux, de modo a apagar traços temporais e espaciais entre o passado nazista alemão e o presente ditatorial brasileiro:

Quer-se impedir que os estudantes hoje e os intelectuais amanhã assumam o seu papel natural de líderes do povo. O golpe golpeou o povo inteiro. E em seguida foi golpeado e arruinado o próprio país; e os próprios golpistas serão os primeiros a sentir o destino amargo que prepararam..$^{21}$

Mensagem transmitida, Carpeaux encerra o último parágrafo com o recurso irônico, que destaca a sua "confusão" e tem como função chamar a atenção do leitor para a "coincidência” entre as experiências alemã e brasileira:

Relendo estas últimas linhas, percebo uma mistura tola dos tempos dos verbos: "deixamos", "não é", "foi o fim", "feriram-se", "quer-se impedir", "serão os primeiros”, "preparam” - o que é isto? É a confusão causada pelas coincidências de que nós outros não somos os responsáveis. ${ }^{22}$

Enquanto o segundo inverno marchava para completar o seu próprio ciclo, Carpeaux seguia montando sua intervenção política através da linguagem esópica, do expediente alegórico. Para além das “coincidências” históricas,

19 CARPeAux, Otto Maria. O Brasil no espelho do mundo. Op. cit., pp. 132-133.

20 Ibidem, p. 133.

21 Ibidem.

22 Ibidem. 
fazia convergir os assuntos internacionais daquele contexto com assuntos políticos brasileiros, com uma forte carga crítica para os últimos.

Para contrastar com o ataque do regime militar às bases constitucionais, Carpeaux louva a sesquicentenária constituição norueguesa ${ }^{23}$ sobre o uso moralista da política, que "pretende limpar e purificar o país", escreve sobre o quarto centenário de Shakespeare e suas peças políticas,${ }^{24}$ sobre expressões e metáforas castrenses ora empregadas no Brasil, como "ofensiva, limpeza do terreno, perseguição impiedosa do adversário", o exemplo cruento e real da Guerra do Vietnã. ${ }^{25}$ Para se contrapor ao projeto moderno-conservador de reforma agrária, implementado pelo regime militar através do Estatuto da Terra, Carpeaux escreve sobre a questione meridionale italiana, "tão parecida com nosso problema no Nordeste", bem como sobre a mezzadria, a versão italiana do nosso "sistema de meia", demonstrando que:

A pseudoreforma-agrária-cristã é um pretexto hipócrita de falsos cristãos e que a definição da reforma agrária como 'questão de consciência' é uma mentira de ignorantes e mercenários e que a força física não adianta a longo prazo nem a curto prazo e que o mundo será livre sem mezzadria nenhuma - ou não será. ${ }^{26}$

Carpeaux, para quem as caminhadas por Florença ensinaram o realismo histórico e a perfeita e terrível atualidade dos versos de Dante, ${ }^{27}$ não demora em citar o expediente que vinha exercitando em sua coluna de política internacional. Sob o pretexto de responder a cartas de leitores, possivelmente estranhando o teor e os enfoques das últimas colunas, escreve outra em que joga com o desvelamento e o encobrimento do truque, sem o risco de comprometê-lo de todo - ou, numa outra leitura, acelerando o fim daquele ciclo e o início de outro. "Língua esópica”, esclarece Carpeaux, "é a arte de falar de uma coisa, parecendo falar de outra. [...] A necessidade do uso da linguagem esópica pode acontecer em 434 antes da nossa era ou em 1934 ou em $1964 ” .{ }^{28}$ E segue:

\footnotetext{
23 CARPEAUX, Otto Maria. “17 de maio”. In: O Brasil no espelho do mundo. Op. cit., pp. 29-30.

24 Ibidem. "A política segundo Shakespeare”, pp. 43-44.

25 Ibidem. "Tiros sem eco", pp. 47-48.

26 Ibidem. "A reforma e a inconsciência”, pp. 60-61.

27 Ibidem. "Meu Dante”, pp. 26-27.

28 Ibidem. "Duas notas inatuais", p. 39.
} 
Em nosso tempo, Georg Lukács alegou usá-la para deixar de irritar as autoridades comunistas, na Hungria e na Rússia. Na Antiguidade, Xenofonte usou-a no diálogo filosófico-político Hieron, para não irritar o tirano que dominava Siracusa. [...] Em 1934, no tempo do fascismo predominante na Europa, Bertolt Brecht justificou o mesmo recurso estilístico no pequeno tratado "Sobre as cinco dificuldades principais que surgem quando se pretende dizer a verdade”. [...] Não se trata de tornar o discurso incompreensível, mas torná-lo comunicável. ${ }^{29}$

Ao final daquelas "notas inatuais", um P.s. esclarecedor do caminho que Carpeaux estava disposto a trilhar, dos exemplos que lhe inspiravam e dos interlocutores com quem desejava se aliar para travarem a luta contra a ditadura militar:

P.S. Ainda me escreve um leitor, manifestando sua confiança na mocidade de hoje que criará, amanhã, um mundo melhor. Sim, amanhã ou depois. Mas não esqueçam os velhos: com o Resistente Número Um da França, De Gaulle, 74 anos, e com o Resistente Número Um do Mundo, Bertrand Russel, 92 anos, e com a fé num futuro em que os moços de hoje também serão, como esses velhos, indomáveis..$^{30}$

\section{NOVAS FRENTES, OUTROS CÍRCULOS E SÍTIOS}

Visualizemos a cena: noite abafada de verão carioca. Cerimônia de colação de grau das turmas de Filosofia, Ciências Sociais e História da Faculdade de Filosofia da Universidade Federal do Rio de Janeiro. No auditório lotado, estudantes e agentes do Dops ajudam a elevar ainda mais a temperatura, que atinge o ápice quando o presidente da solenidade interrompe o discurso da oradora e ameaça: "Eu não admito que a senhora continue a falar nesse tom. Isto não é um discurso de formatura, mas sim um manifesto subversivo, e se ele continuar, declaro encerrada a solenidade". Ao que Otto Maria Carpeaux, paraninfo da turma, levanta-se, dá um murro na mesa, e contra-ataca: "Se quiser sair, que saia, pois de agora em diante eu assumo a presidência da mesa". Sob vaias, o professor abandona a presidência da solenidade, Carpeaux

29 Ibidem. "Duas notas inatuais". p. 39.

30 Ibidem, p. 40. 
assume o seu posto e a oradora da turma termina o seu discurso, em que eram feitas críticas tanto ao governo brasileiro quanto à “agressão imperialista no mundo todo, principalmente no Vietnã". ${ }^{31}$ Em tempo, o homenageado da turma era Régis Debray, o jovem filósofo francês autor de Revolução na revolução, então preso na Bolívia acusado de integrar o grupo guerrilheiro de Che Guevara.

Cenas como essa, ocorrida em janeiro de 1968, seguidas da repercussão nos meios de comunicação do país, tornaram-se tão certas nos finais de ano como as próprias formaturas. Podem ser tomadas como um dos flancos do movimento estudantil - que, por sua vez, foi um dos setores fundamentais da resistência ao regime militar e, num segundo momento, a principal fonte para a composição dos grupos de guerrilha daquela época. ${ }^{32}$

A presença de Carpeaux nessas solenidades também se tornou uma constante. Entre 1964 e 1968, há registro de pelo menos oito cerimônias de formatura em que ele figurou como paraninfo ou patrono de turma. ${ }^{33}$ Assumindo um tom menos alegórico que em seus artigos do Correio da Manhã, mas não menos irônico, suas falas eram de críticas diretas ao regime militar, emprestando autoridade aos discursos dos formandos.

Na solenidade de formatura do ano anterior da Faculdade de Filosofia da Universidade Federal do Rio de Janeiro, no Teatro Municipal, Carpeaux destacou a escolha do grupo de formandos em nomear dom Helder Câmara como seu patrono, demonstrando "uma profissão de fé humanística" e que não se calariam "diante de injustiças e violências, como a que sofreu o sargento Manuel Raimundo Soares" - em referência a um dos primeiros casos de tortura e morte por parte dos órgãos de repressão sobre o qual se teve notícia na época. ${ }^{34}$ De forma irônica, confirmou que o tema de seu discurso era mesmo a ditadura e que "há muitos anos ele

\footnotetext{
31 CARPEAux, Otto Maria. "Formatura acidentada". Folha de S.Paulo, 19 jan. 1968, p. 3.

32 Em recente publicação, o historiador Rodrigo Patto Sá Motta descreve outros exemplos da "prática de usar as cerimônias de colação de grau como estratégia de denúncia da ditadura, com discursos dos representantes de turma e a escolha de paraninfos desafetos ao regime militar”. Cf. мотTA, Rodrigo Patto Sá. As universidades e o regime militar. Rio de Janeiro: Zahar Editora, 2014 e sANTANA, Flávia Angelis. Atuação política do movimento estudantil no Brasil: 1964 a 1984. Dissertação (Mestrado em História) - Faculdade de Filosofia, Letras e Ciências Humanas, Universidade de São Paulo, 2007.

$33 \mathrm{O}$ fato de a maioria dos convites dessas solenidades comporem o arquivo de Otto Maria Carpeaux na Fundação Casa de Rui Barbosa é indicativo da importância da sua proximidade com os estudantes, levada em conta pelos organizadores do arquivo e, sobretudo, pela sua doadora, Helena Carpeaux. Conferir as 77 folhas de convites de formatura no Acervo da Fundação Casa de Rui Barbosa. Arquivos Pessoais de Escritores Brasileiros - АРEB. Fundo/Coleção: Otto Maria Carpeaux.

34 "Rio: Filosofia cola grau com protestos". Folha de S.Paulo, 3 jan. 1967, p. 3. Manuel Raimundo Soares foi um dos líderes do Movimento Nacionalista Revolucionário, organização formada em torno de Leonel Brizola, responsável pela Guerrilha do Caparaó.
} 
pretendera viajar pelo continente para conhecê-la, mas, como era muito perigoso, preferiu ficar em casa até que ela um dia viera visitá-lo”. ${ }_{35}$

Não raro, essas participações serviram para indispor Carpeaux com as autoridades ou com os defensores do regime militar. Ao fim daquela cerimônia de 1968 da Faculdade Nacional de Filosofia, ao discutir com o professor presidente da solenidade, tomar o seu lugar e garantir a continuidade do discurso da estudante, Carpeaux foi detido por algumas horas para interrogatório. ${ }^{36} \mathrm{Já}$ na solenidade da Escola de Engenharia de São Carlos, da USP, convidado como paraninfo, mas não podendo comparecer, Carpeaux pediu para que Antonio Candido o substituísse e lesse o seu discurso. "Naturalmente pouco lisonjeiro em relação ao governo", aquelas palavras fizeram com que Candido se indispusesse com o vice-reitor; este, como representante da universidade na cerimônia, defendeu o regime militar e rebateu as críticas de Carpeaux. ${ }^{37}$

A proximidade com o movimento estudantil e com outros interlocutores também se intensificou à medida que Carpeaux passou a colaborar com a Revista Civilização Brasileira e com outros periódicos surgidos na época, muitos de abrangência e vida curtas, mas que se somaram ao grande arco de reflexão e debate da intelectualidade brasileira e de oposição ao regime militar. São exemplos de colaborações pontuais ou regulares de Carpeaux naquele contexto: Folha da Semana, editado por Arthur Poerner, que também contava com a colaboração de Sérgio Cabral, Leandro Konder, Carlos Nelson Coutinho, dentre outros; jornal Reunião, editado por Ênio Silveira e dirigido por Paulo Francis; revista Política Externa Independência, pertencente ao leque das edições da Civilização Brasileira; jornal Amanhã, ligado aos estudantes da Faculdade de Filosofia da rua Maria Antônia, e do qual Carpeaux era um dos poucos autores a assinar os artigos, dada a natureza semiclandestina da publicação; e o jornalescola $\mathrm{O} S o l$, criado e editado no Rio de Janeiro a partir de $1967 .{ }^{38}$

Segundo o estudo de fôlego de Bernardo Kucinski sobre a imprensa alternativa dos anos 1960 e 1970, a importância histórica de publicações como Amanhã e $O$ Sol reside no seu protagonismo como "frente jornalística", através da qual vários partidos de esquerda,

\footnotetext{
35 Ibidem.

36 воSI, Alfredo. "Relendo Carpeaux". In: Estudos Avançados, v. 27, n. 78, set./dez., São Paulo, 2013, p. 289. 37 мотта, Rodrigo Patto Sá. Op. cit.

38 KUCINSKi, Bernardo. Jornalistas e revolucionários. São Paulo: Página Aberta, 1991, p. 20.
} 
mesmo mantendo seus jornais clandestinos ou partidários, puderam se unir para a sustentação de um jornal ou revista produzidos "sob padrões técnicos de mercado, voltado não só aos seus militantes, mas também a um público externo e distribuído nacionalmente”. ${ }^{39}$ Além da abrangência e da propaganda junto aos setores urbanos que a frente jornalística pudesse angariar, ${ }^{40}$ jornais como Amanhã também eram de extrema importância para a política de atração de novos quadros para os grupos guerrilheiros.

Ao que tudo indica, esse também foi o caso de $O$ Sol e do grupo que o gravitava, o Movimento Nacionalista Revolucionário. Surgido do movimento dos sargentos e marinheiros liderados por Leonel Brizola, o MNR foi o primeiro grupo a se lançar às armas, ainda em 1964. Tentara fixar três focos guerrilheiros rurais, dos quais somente um foi plenamente estabelecido, o da Serra do Caparaó. A Guerrilha do Caparaó, como ficou conhecida, começou a ser preparada em 1966 e foi desarticulada pela ditadura militar em abril de $1967 .{ }^{41}$

Antes de $O$ Sol, um importante parênteses: embora nunca tenha sido comprovado, há indícios de que tanto Carpeaux quanto Carlos Heitor Cony, Antonio Callado e Thiago de Mello estiveram envolvidos com o estabelecimento da guerrilha em Caparaó, realizando "tarefas" que iam do transporte de armamentos ao transbordo de mensagens e contatos, sobretudo entre Rio de Janeiro e São Paulo. Em depoimento a Bernardo Kucinski, Antonio Callado - àquela altura demissionário do Correio da Manhã, como também o eram Carpeaux e Cony -, descreve em detalhes a tarefa atribuída a Carpeaux pelo movimento guerrilheiro:

Decorar mensagens muito importantes, longas, com endereços, indicações. Levava tudo aquilo na cabeça. Podiam prender o Carpeaux quanto tempo quisessem, ele não tinha um fiapo de informação. Era só ele, gago, estrangeiro, indo ao Recife, por exemplo, a propósito de fazer alguma coisa. Chegava lá, ele contava tudo aquilo. É como se você mandasse um folheto

\footnotetext{
39 Ibidem, p. 24.

40 No caso do Amanhã, por exemplo, o fim da estabilidade funcional e a subsequente introdução do Fundo de Garantia por Tempo de Serviço (FGTS), frutos da política trabalhista conservadora do governo militar, ocupou quase todas as seis edições existentes do jornal. Também a linguagem direta, que convidava o leitor ao diálogo, "sem o ranço que caracterizaria tantos jornais alternativos", concorreu para a promoção do Amanhã junto à "classe operária desarticulada pela repressão".

41 Sobre a Guerrilha da Caparaó, cf. costa, José Caldas da. Caparaó: a primeira guerrilha contra a ditadura. São Paulo: Boitempo, 2007. Sobre o envolvimento de intelectuais e artistas na sua articulação, cf. RIDENTI, Marcelo. Em busca do povo brasileiro: artistas da revolução, do CPC à era da TV. Rio de Janeiro: Record, 2000.
} 
impresso. E é claro que havia risco nisso, se ele fosse torturado etc. Foi uma atividade revolucionária de extrema originalidade, muita utilidade e perigo. Estou contando isso para ver como uma pessoa podia prestar serviços importantes e que se perderam depois. ${ }^{42}$

Ainda segundo Kucinski, alguns dos remanescentes do Caparaó "aproximaram-se de um grupo de artistas, jornalistas e intelectuais cariocas engajados na discussão de um jornal que 'fosse uma escola de jornalismo"'43. Entre os quais, Dedé Gadelha, Ana Arruda, Zuenir Ventura e Henfil. Reynaldo Jardim, um dos responsáveis pela reforma gráfica do Jornal do Brasil dos anos 1950, criador do Caderno B e do Suplemento Dominical do Jornal do Brasil, foi um dos nomes que integraram a equipe, que ainda contava com Cony, Ziraldo, Nelson Rodrigues, Ruy Castro, dentre outros.

A instrumentalização de $O$ Sol pelo MNR não é consenso. As entrevistas conduzidas por Kucinski para o seu estudo, somadas à total ausência desse dado nos depoimentos de um documentário produzido sobre $O S_{\text {Sol }}{ }^{44}$ ao menos apontam para uma maior complexidade em torno dessa ilação. Jorge Pinheiro, por exemplo, militante do MNR que anos depois se exilaria no Chile de Salvador Allende, afirmou a Kucinski que teve contato e entrou para aquele grupo guerrilheiro n'O Sol; que fora "recrutado lá dentro": "O MNR já tinha feito a primeira guerrilha e estávamos nos organizando para outra... houve influência da revolução cubana. Resolvemos nuclear jovens, utilizando o jornalismo". ${ }^{45}$ Porém, na nota de referência àquela entrevista, Kucinski pontua: "Alguns participantes centrais d'O Sol e de seu sucessor, Poder Jovem, nunca souberam de sua instrumentalização pelo MNR". ${ }^{46}$

Ao largo disso, o que se depreende da história de $O S o l$ é sua ligação com uma parcela jovem da população do Rio de Janeiro, onde era produzido e onde circulava, tanto por sua linha editorial, de forte teor contestatório e crítica ao regime militar e aos setores moderados de oposição, quanto pelos seus aspectos formais, que tinha na sua audaciosa

\footnotetext{
42 KUCINSCI, Bernardo. Op. cit., pp. 147-148.

43 Ibidem, p. 33.

44 Além da obra de Bernardo Kucinski, ver o documentário O Sol: caminhando contra o vento. Direção: Tetê Moraes e Martha Alencar. Rio de Janeiro: RioFilme; Vemver Brasil, 2006, DVD.

45 KUCINski, Bernardo. Op. cit., p. 33.

46 Ibidem, p. 135 [nota 36].
} 
diagramação, "ora concretista, ora psicodélica", ${ }^{47}$ e no seu modelo de "jornal-escola" as suas principais armas.

A ideia de contar com um corpo fluido de estudantes na equipe do jornal, de treinar e "adestrar" esses jovens para que desenvolvessem uma linguagem jornalística direta, coloquial, foi uma preocupação para aqueles que pensaram na sua existência. Ana Arruda, uma das jornalistas envolvidas na criação de $O S o l$, é quem explica parte do conceito:

Era um jornal-escola e nós fizemos um seminário [de] dois dias na casa do Reynaldo Jardim em [Nova] Friburgo, no sítio, [com] todos os editores, os estudantes e com repórteres, discutindo o jornal, fazendo a linha do jornal; e antes de sair o primeiro número teve um curso, em que o Carpeaux dava aula, o Zuenir dava aula, o Reynaldo dava aula, eu dava aula. A gente fazia o curso para [que] os alunos ficassem mais adestrados, mais informados. ${ }^{48}$

\section{O VELHO E O NOVO - IMAGENS EM MOVIMENTO}

"A trajetória do intelectual Otto Maria Carpeaux e a realidade política do Brasil após o golpe militar de 1964" é a sinopse de O velho e o novo (Otto Maria Carpeaux), um média-metragem de 30 minutos produzido entre 1966 e 1967 por um autodenominado grupo de admiradores do austríacobrasileiro e dirigido por Maurício Gomes Leite. ${ }^{49}$

Qual uma síntese entre as imagens do Anschluss austríaco e do golpe de 1964, o plano inicial da primeira sequência de $O$ velho e o novo é composto por imagens de jovens em passeata; jovens de feições compenetradas, iracundas ou mesmo sorridentes - especialmente quando percebem a captação de suas imagens pela câmera filmadora. Possivelmente apresentam o mesmo clamor que Carpeaux, então Karpfen, percebera na juventude austríaca à face das tropas de Hitler. Porém, além do idioma presente nas faixas que empunham e nos gritos que ecoam, o que os diferencia daqueles outros jovens de outrora e alhures é sua postura de enfrentamento, de oposição a um regime

47 Ibidem, p. 34.

48 O Sol: caminhando contra o vento. Op. cit.

49 O velho e o novo (Otto Maria Carpeaux). Direção: Maurício Gomes Leite, 1967. Guanabara: CAIC; Tecla Filmes [PB, 16mm, $30 \mathrm{~min}$.]. Por questões relacionadas aos direitos autorais, cópias do filme são raridades. Até o limite de nossa consulta, conseguimos mapear somente uma delas, depositada na Cinemateca do MAM/ RJ. Deixamos registrado os agradecimentos a Hernani Heffner, conservador da cinemateca em 2015, pela exibição do filme. Afora as referências colhidas da análise de Jean-Claude Bernardet em Cineastas e imagens do povo, as citações que se seguem provêm das nossas anotações. 
autoritário, violento e não democrático. Ao fim do primeiro plano, que também inclui imagens estáticas dos estudantes em marcha, um primeiro letreiro indica tratar-se de "uma reportagem filmada", por ora sem título.

No segundo plano da sequência, antes mesmo dos títulos e dos créditos iniciais, somos apresentados à personagem que coprotagoniza O velho e o novo: são imagens de Otto Maria Carpeaux sentado em seu caseiro gabinete de trabalho, com o tronco curvado em direção à mesa, escrevendo com teatral compenetração numa folha de papel. Em seguida, depois de tragar seu cigarro, levanta-se e dá alguns passos em direção à pequena estante às suas costas. De livro em punho, traga uma vez mais o cigarro e senta-se para transcrever a citação que se fez necessária.

Se de fato está escrevendo um dos seus inúmeros artigos de intervenção política ou simplesmente representando tal ato, pouco importa. Para a tarefa que sua personagem deverá desempenhar ao longo do curta-metragem, o plano é deveras auspicioso, pois o representa no ato próprio da citação, da articulação entre o passado e as demandas previstas naquele contexto.

Mas qual seria essa tarefa? Os créditos finalmente aparecem e dois deles merecem a nossa atenção: "Leitura dos textos de Carpeaux: Tite de Lemos" e "Participação de Lygia Sigaud". O último plano da primeira sequência não nos ajuda muito em relação à tarefa da personagem Carpeaux. Ele apenas reforça o universo profissional da personagem-título do filme, através de dois rápidos travellings pelos livros enfileirados numa mesa contígua à mesa de trabalho, ainda no apartamento do escritor. A resposta reside nos primeiros planos da segunda sequência. Paradoxalmente, não é Carpeaux quem os protagoniza, e sim uma jovem estudante. Após algumas imagens, entre ruas, casas urbanas e ruínas de um terreno baldio (seria no Rio de Janeiro?), somos formalmente apresentados àquela jovem. Ou melhor, ela mesmo se apresenta: uma estudante de sociologia, de 22 anos, que trabalha num jornal e que tem por tarefa ir ao encontro do homem cujo nome "acostumou-se a ouvir nos intervalos das aulas da PUC/RJ" - "preciso saber o que há de mais íntimo sobre Otto Maria Carpeaux", resume Lygia Sigaud. Ou seria Martha, o nome da sua personagem no filme?

Estruturalmente, sua personagem complementa a tarefa de Carpeaux; dá sentido a ela. O velho e o novo. Desde o título, é esse encontro que articula a trama. "Em todas as ações e movimentos de vossos personagens, buscai sempre o velho e o novo", diz Lygia Sigaud, citando Bertold Brecht. Ou já seria Martha? Isso porque o flerte com o caráter ficcional 
se completa com a figura de Sigaud em pleno teste cinematográfico. Carpeaux seria o responsável por fazer daquela estudante uma "aspirante a atriz". "Fiz um teste e passei”, diz Sigaud/Martha, pouco antes de citar a frase de Brecht. Como observou Jean-Claude Bernardet num pequeno artigo sobre o filme, o plural "personagens" daquela frase permite estender a noção ao próprio Carpeaux..$^{50}$ Desde a sua primeira tomada, de gestos hiperbólicos para a sensível captação fílmica, não há como ter outra impressão do austríaco-brasileiro.

A potência do filme dirigido por Maurício Gomes Leite reside na síntese-título entre o intelectual sexagenário e a estudante universitária, mas vai além. Na forma como foi montado, uma linha divisória nos conduz para um antes e depois na vida de Otto Maria Carpeaux. A certa altura do filme, em off, a personagem Martha diz: “1964, março, 31”. Um letreiro surge à tela para complementar "Carpeaux narra o filme". Em seguida, ouvimos mais uma vez a voz de Martha: "Um outro trabalho começa. Para Carpeaux, já não é uma sobrevivência. É uma vivência que luta". É só a partir desse momento que Carpeaux ganha "voz" - não literalmente, mas através da leitura em off de textos de sua autoria, lidos por um locutor profissional, Tite de Lemos.

Como resultado desta montagem, temos: "um homem imerso em livros e na cultura europeia", o golpe de 1964, pontuado em off pela personagem de Lygia Sigaud, e a ação política de Carpeaux que, ao passar a "narrar o filme”, assume um papel político, “o que vai se dar, em sua qualidade de escritor, pela palavra, pelo discurso". ${ }^{51}$ Não deixa de ser montagem eficiente, pois dá início à compatibilização entre a diegese do filme e o contexto em que ele seria exibido, ${ }^{52}$ fazendo com que as imagens de tomadas anteriores, sobretudo aquelas sobre a ascensão do nazismo, do próprio Hitler, de batalhas da Segunda Guerra Mundial, de cadáveres ou de pessoas sendo libertadas de campos de concentração, fossem "acomodadas" como mero recurso didático de acesso ao passado de Carpeaux.

Sob uma leitura formalista, essas imagens do passado europeu de Carpeaux poderiam ser tomadas como uma espécie de passaporte, de qualificação para a sua atuação política naquele contexto brasileiro. Seria,

\footnotetext{
50 BERNARDET, Jean-Claude. “A outra vertente. O velho e o novo. Cultura e loucura”. In: Cineastas e imagens do povo. São Paulo: Editora Brasiliense, 1985, p. 126.

51 Ibidem, p. 129.

52 Com mais duas atualizações temporais ("1965, novembro" e "1966, setembro"), o filme chega ao seu final coincidindo com o contexto de sua exibição, ainda sob o regime ditatorial, fator que o potencializa enquanto objeto de intervenção daquele contexto.
} 
portanto, uma voz qualificada, que uniria o voluntarismo e a transição de um personagem como Paulo Simões, do romance Pessach, à experiência histórica de quem vivera as consequências de um regime de exceção. ${ }^{53}$ Para aqueles que haviam acompanhado a já extinta coluna de política internacional assinada por Carpeaux no Correio, tais imagens também poderiam representar a transposição para o suporte cinematográfico da deliberada aproximação entre nazismo e ditadura militar. Não por acaso, quando Carpeaux detém o "poder de fala" no filme, o primeiro texto que se ouve de sua autoria é justamente aquele em que ele esclarecia a seus atônitos leitores o que era a linguagem esópica.

$O$ início da segunda parte de $O$ velho e o novo, que passa a ser "narrada" por Carpeaux, também marca a passagem da alegoria para a frente das câmeras; no limite, podemos dizer que ela se torna uma nova personagem e chega mesmo a ser devidamente apresentada aos espectadores. É notório que a linguagem alegórica como solução formal atravessa $O$ velho e o novo desde o primeiro plano do filme. Além disso, no que se refere à estratégia de plasmar "a transição política" de Carpeaux aos elementos formais do filme, ganham destaque a palavra, instrumento de sua ação política, e a alegoria.

Os pares dicotômicos movimento-positividade e imobilismonegatividade, outro elemento formal da montagem do filme, também estão à serviço da alegoria. Na primeira sequência da segunda parte, por exemplo, ganham destaque imagens de um meio social diverso daquele em que $O$ velho e o novo era majoritariamente ambientado e de onde provinham seus protagonistas. São imagens captadas num bairro visivelmente afastado do centro político e intelectual do estado da Guanabara: de um trem cheio, em movimento, atravessando uma avenida também repleta de carros e pedestres, ou de pessoas atravessando a passarela da linha do trem, compenetradas nos seu ir-e-vir cotidiano. Um corte e somos transportados para o Tirol, a Boêmia ou qualquer outra região alpina que mulheres em trajes folclóricos imaginam estar, captadas de alguma Feira das Nações transladada aos trópicos. Outro corte e somos apresentados a uma das tomadas mais alegóricas do filme: surgem na tela três ou quatro manequins, modelos em tamanho infantil, todos vestidos impecavelmente e na posição que lhes é natural. Como resultado

53 Personagem do romance Pessach, de Carlos Heitor Cony, publicado em 1967, sobre um escritor pequeno-burguês que, com o golpe de 1964 e a instauração da ditadura, adere à luta armada. 
do travelling, o enquadramento inicial vai cedendo à abertura do plano, quando se percebe de fato se tratar de uma vitrine de loja infantil. Mais uma abertura e já podemos ver, do outro lado da vitrine, três ou quatro crianças, possivelmente moradores de rua, descalças e com roupas puídas que, entre olhares e gestos voltados para o interior da vitrine, alternam a admiração pelos manequins e pela câmera que as capta. Ao fim, o plano novamente se fecha, no mesmo sentido em que havia começado, em direção às outras "crianças" bem-vestidas, limpas e estáticas.

Da primeira sequência, pode-se depreender tanto a crítica direta à autodenominada "Revolução Redentora", incapaz de abolir iniquidades históricas, quanto a crítica ob-reptícia ao imobilismo, ali representado pelos manequins e pelos trajes folclóricos - espécie de cristalização da cultura.

Na sexta e última sequência da segunda parte, novamente aqueles pares dicotômicos são trabalhados. Ela é aberta com a inserção em off de Martha, que anuncia: “1966, setembro”. Em seguida, imagens de estudantes em protesto invadem a tela, agora andando em meio aos carros - praticamente parados no trânsito pesado de fim de tarde -, segurando faixas e entoando gritos que parecem ser de protesto. $\mathrm{Ou}$ estariam cantando? Não há captação direta do som, e o que ouvimos é um trecho da música "Roda", de Gilberto Gil - "Quero ver quem vai sair/ Quero ver quem vai ficar". O uso intercalado de uma ou outra fotografia desses jovens potencializa suas próprias imagens em movimento. $\mathrm{O}$ contraste é maior pela tomada subsequente, montada apenas com imagens estáticas de pessoas mais velhas e visivelmente desoladas.

$\mathrm{O}$ que aquela data representa na estrutura narrativa de $O$ velho e $o$ novo, capaz de gerar protestos e sentimento de derrota? Quem eram e o que fizeram os inimigos? Fosse outubro de 1966, poderíamos supor uma referência à eleição indireta que elegeu Costa e Silva para a presidência da República. Fosse agosto de 1966, a referência poderia ser a morte do sargento Manuel Raimundo Soares, líder do Movimento Nacionalista Revolucionário ${ }^{54}$ Fosse julho, suporíamos tratar-se da eliminação da seleção brasileira na Copa do Mundo de futebol. ${ }^{55}$ Então, por que setembro de 1966 ?

\footnotetext{
54 Não se tratou de uma notícia generalizada, mas circunscrita aos movimentos de esquerda, sobretudo ao grupo que posteriormente faria subsistir a Guerrilha do Caparaó.

55 Para a produção do filme, essa referência não é gratuita. Segundo Sérgio Augusto, um dos produtores, imagens de pessoas desoladas e visivelmente tristes foram captadas justamente no dia em que a Seleção brasileira de futebol perdeu para a seleção portuguesa e foi eliminada da Copa do Mundo da Inglaterra, em 19 de julho de 1966. "Por coincidência, quando de nossa fatídica cruzada à Inglaterra, em 1966, filmávamos, Maurício Gomes Leite, José Carlos Avellar, Geraldo Mayrink e eu, um documentário sobre Carpeaux. No dia em que a Seleção brasileira jogou sua derradeira cartada, contra Portugal, corremos ao centro da cidade para registar
} 
A resposta pode estar na tomada seguinte, a última daquela sexta e derradeira sequência. Enquanto ouvimos Martha narrar "forma-se o cerco contra Carpeaux. O que a polícia não fez, o silêncio começa a fazer. Após dezesseis anos de atividade diária no jornal, sua voz é abafada”, surge uma série de imagens estáticas de Carpeaux no edifício do Correio da Manhã. É a primeira vez em que ele é retratado ali, no seu "lugar de lutas", andando pelos corredores, pelo Petit Trianon, pelo restaurante do jornal. A solução formal aplicada nesta tomada é sui generis: como é formada por fotografias sequenciadas, há um certo efeito de movimento na cena.

Premido por censura política e econômica, seria a vez do Correio da Manhã "optar" pela inércia. A forma encontrada foi "abafando" ou expurgando vozes dissonantes ao regime militar. Uma dessas vozes, Carpeaux foi proibido pela direção do jornal de voltar a assinar colunas políticas. Meses depois - setembro de 1966 - Carpeaux deixaria o jornal, escolhendo o "novo".

No epílogo de $O$ velho e o novo há, finalmente, o encontro entre Carpeaux e Martha, personagem de Lygia Sigaud. Numa captação externa, envolvidos entre um edifício varandado e um passeio público, Carpeaux e Martha parecem travar um diálogo ameno, como amena é a música inicialmente introduzida em fade in e acentuada ao longo da cena. Seja pela música, seja pela abertura acentuada do plano, não se ouve aquele diálogo. Captados inicialmente em plano americano - primeiro parados, depois andando em direção à tela - suas figuras quase submergem ao panorama urbano graças ao recuo abrupto da câmera, que termina em plano geral e com a fotografia estourada pela forte incidência da luz solar. Igual movimento é feito pelo letreiro "O novo" que, também em zoom invertido, parte pequeno do meio das figuras também diminutas de Carpeaux e Martha para ocupar a tela toda e, assim, fechar o filme.

Segundo a arguta análise de Jean-Claude Bernardet, embora esse encontro represente um "ponto de chegada positivo" para o filme, ele também é melancólico. "A conversa que não se ouve, o silêncio até a entrada da música suave, a fotografia estourada que cobre as imagens de um branco leitoso" são, segundo o crítico, os elementos finais que

\footnotetext{
o 'mood' dos torcedores, agrupados em torno dos alto-falantes instalados na Cinelândia, a televisão pública da época. Esperávamos a vitória. A derrota, porém, nos serviu como as uvas à raposa. Contemplando a massa em lerda e deprimida debandada, alguém da equipe ponderou: 'Assim ao menos vai combinar melhor com o espírito do filme'. Todos concordaram. Para Carpeaux, a derrota combinava melhor com o Brasil de 1966, derrotado, dois anos antes, por um golpe militar que ele amaldiçoou até o fim da vida". Cf. AUGUSTO, Sérgio. "Os intelectuais e a discussão sobre o papel do futebol”. Folha de S.Paulo, Ilustrada, 10 jun. 1982, p. 3.
} 
ratificam a construção da personagem Carpeaux pelo filme como a de um intelectual agônico; portador de uma "ação corajosa [enfrentar verbalmente a ditadura militar] mas ineficiente, talvez inadequada". ${ }^{56}$

Insistimos numa leitura diferente. Desde a escolha do plano geral, passando pelo diálogo entre os dois protagonistas, chegando ao "novo" que salta, hiperdimensionado, à tela, podemos ler essa tomada final como alegoria de uma obra aberta - quer seja do filme, quer seja dos destinos daquelas personagens. Mesmo o silêncio, de fato imposto sobre Carpeaux e que seria paulatinamente generalizado aos intelectuais e artistas pelo arbítrio da censura, pode ser contrastado se tomado pela ótica da resistência, do movimento que urge necessário para rompê-lo, para romper a censura.

Se a perda de seu emprego, "de sua voz" no Correio da Manhã, foi uma consequência direta de seu posicionamento político, o encontro com a jovem universitária na última cena indica que o caminho era mesmo o novo. Ou seja, na narrativa interna do filme, trata-se de um epílogo positivo; propositivo. ${ }^{57}$ Movimentando-se fora das telas como se desse continuidade àqueles passos finais de $O$ velho e o novo, Carpeaux ocuparia outras frentes na mídia impressa - incluindo a imprensa ligada a grupos guerrilheiros -, estabeleceria uma grande proximidade com o movimento estudantil e seria figura presente em cerimônias de formatura e assembleias estudantis Brasil afora.

Ao mesmo tempo, esse conjunto de ações em prol da "luta pela libertação do povo brasileiro" só pode ser melhor compreendido se levarmos em conta a atuação política europeia de Carpeaux pré-exílio, quando ele próprio era um estudante comprometido com o programa clerical e conservador do Partido Social Cristão austríaco, embora contrário ao Anschluss. Um passado redivivo com o assalto ao poder de 1964 que, a despeito de todos os reveses, contribuiu para que Carpeaux reelaborasse sua biografia, "seu plot bem inventado", e fosse ao encontro do novo.

EDUARDO GOMES SILVA é pós-doutor em História pelo PPGH/UFSC e autor de Imagens de Otto Maria Carpeaux: esboço de biografia.

56 BERNARDET, Jean-Claude. Op. cit., pp. 134-135.

$57 \mathrm{O}$ contraste com o final agonizante da personagem Paulo Martins, de Terra em transe, não poderia ser mais explícito. 